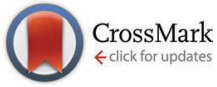

Cite this: J. Mater. Chem. C, 2016, 4, 9872

Received 9th August 2016, Accepted 22nd September 2016

DOI: $10.1039 / c 6 t c 03422 e$

www.rsc.org/MaterialsC

\section{New $\mathrm{Y}_{2} \mathrm{BaAl}_{4} \mathrm{SiO}_{12}: \mathrm{Ce}^{3+}$ yellow microcrystal-glass powder phosphor with high thermal emission stability $\dagger$}

\author{
Haipeng Ji, ${ }^{\text {ab }}$ Le Wang, ${ }^{\star c}$ Yujin Cho, ${ }^{\text {bd }}$ Naoto Hirosaki, ${ }^{b}$ Maxim S. Molokeev, ${ }^{\text {ef }}$ \\ Zhiguo Xia, ${ }^{9}$ Zhaohui Huang ${ }^{* a}$ and Rong-Jun Xie ${ }^{* \text { bh }}$
}

\begin{abstract}
To decrease the rare earth element usage and synthesis cost of $\mathrm{Y}_{3} \mathrm{Al}_{5} \mathrm{O}_{12}$ : Ce phosphor, the $\mathrm{Y}_{2} \mathrm{BaAl}_{4} \mathrm{SiO}_{12}$ compound is developed as a new host for $\mathrm{Ce}^{3+}$ employing the solid solution design strategy. The design uses polyhedron substitution where $\mathrm{YO}_{8} / \mathrm{AlO}_{4}$ are partially replaced by $\mathrm{BaO}{ }_{8} / \mathrm{SiO}_{4}$, respectively. Structure analysis of $\mathrm{Y}_{2} \mathrm{BaAl}_{4} \mathrm{SiO}_{12}$ proves that it successfully preserves the garnet structure, crystallizing in the cubic la $\overline{3} d$ space group with $a=b=c=12.00680$ (5) $\AA$. Barium (Ba) atoms occupy the $Y$ site and silicon ( $\mathrm{Si}$ ) atoms occupy the $\mathrm{Al}$ site in the $\mathrm{AlO}_{4}$ tetrahedrons. An expanded study on $\mathrm{Y}_{2} \mathrm{MAl}_{4} \mathrm{SiO}_{12}$ $(M=B a, C a, M g, S r)$ series shows a cation size (of $M)$-dependent phase formation behavior. The lattice stability can be related with the $M$ type in the $M-S i$ pair and substitution level of $M-S i$ for $Y-A l$. Doping $\mathrm{Ce}^{3+}$ into $\mathrm{Y}_{2} \mathrm{BaAl}_{4} \mathrm{SiO}_{12}$ yields bright yellow photoluminescence peaking at around $537 \mathrm{~nm}$ upon excitation by $460 \mathrm{~nm}$ light. The emission intensity is quite stable against thermal quenching whereas the peak wavelength shows a slight red-shift as the ambient temperature increases. The crystallization behavior of $\mathrm{Y}_{2} \mathrm{BaAl}_{4} \mathrm{SiO}_{12}$ is suggested as melt-assisted precipitation/growth based on cathodoluminescence analysis. The highly crystalline nature of the microcrystals explains the stable emission against thermal quenching. This study may provide an inspiring insight into preparing phosphor with new morphology-structure of "microcrystal-glass powder phosphor", which distinguishes it from conventional "ceramic powder phosphor" or "single-crystal phosphor".
\end{abstract}

\footnotetext{
${ }^{a}$ National Laboratory of Mineral Materials, Beijing Key Laboratory of Materials Utilization of Nonmetallic Minerals and Solid Wastes, School of Materials Science and Technology, China University of Geosciences (Beijing), Beijing 100083, China. E-mail: huang118@cugb.edu.cn

${ }^{b}$ Sialon Group, National Institute for Materials Science, 1-1 Namiki, Tsukuba 305-0044, Japan. E-mail: XIE.Rong-Jun@nims.go.jp

${ }^{c}$ College of Optical and Electronic Technology, China Jiliang University, Hangzhou 310018, China. E-mail: calla@cjlu.edu.cn

${ }^{d}$ Semiconductor Device Materials Group, National Institute for Materials Science, 1-1 Namiki, Tsukuba 305-0044, Japan

${ }^{e}$ Laboratory of Crystal Physics, Kirensky Institute of Physics, Federal Research Center KSC SB RAS, Krasnoyarsk 660036, Russia

${ }^{f}$ Department of Physics, Far Eastern State Transport University, Khabarovsk, 680021, Russia

${ }^{g}$ The Beijing Municipal Key Laboratory of New Energy Materials and Technologies, School of Materials Sciences and Engineering, University of Science and Technology Beijing, Beijing 100083, China

${ }^{h}$ College of Materials, Xiamen University, Xiamen, China.

E-mail: rjxie@xтu.edu.cn

$\dagger$ Electronic supplementary information (ESI) available: Crystallographic information files (CIF) of $\mathrm{Y}_{2} \mathrm{BaAl}_{4} \mathrm{SiO}_{12}$; evolution of cell volume against ionic radius of $\mathrm{M}$ in $\mathrm{Y}_{2} \mathrm{MAl}_{4} \mathrm{SiO}_{12} ; \mathrm{XRD}$ patterns of $\mathrm{Y}_{2.96-x} \mathrm{Ba}_{x} \mathrm{Ce}_{0.04} \mathrm{Al}_{5-x} \mathrm{Si}_{x} \mathrm{O}_{12}(x=0.08,0.06)$; and XRD patterns of $\mathrm{Y}_{2} \mathrm{BaAl}_{4} \mathrm{SiO}_{12}$ sintered at different temperatures. See DOI: 10.1039/ c6tc03422e
}

\section{Introduction}

White light emitting diodes (WLEDs) are playing a key role in lighting and illumination. ${ }^{1}$ The main way to produce white light from a monochromatic light emitting diode (LED) combines a blue indium gallium nitride (InGaN) with a down-converting phosphor such as $(\mathrm{Y}, \mathrm{Gd})_{3}(\mathrm{Al}, \mathrm{Ga})_{5} \mathrm{O}_{12}: \mathrm{Ce} \quad$ (YAG:Ce), or $(\mathrm{Tb}, \mathrm{Re})_{3}(\mathrm{Al}, \mathrm{Ga})_{5} \mathrm{O}_{12}: \mathrm{Ce}$ (TAG:Ce). ${ }^{2,3}$ Applying YAG and TAG in WLED were patented by the Nichia Corporation and Osram, respectively. Thus, it is of practical interest to find alternative candidates free from intellectual property conflict with YAG/TAG. Several (oxy)nitride candidates such as $\mathrm{Ca}-\alpha$-Sialon: $\mathrm{Eu}^{2+}{ }^{2}(\mathrm{Sr}, \mathrm{Ba})-$ $\mathrm{Si}_{2} \mathrm{O}_{2} \mathrm{~N}_{2}: \mathrm{Eu}^{2+},{ }_{4}(\mathrm{La}, \mathrm{Ca})_{3} \mathrm{Si}_{6} \mathrm{~N}_{11}: \mathrm{Ce}^{3+},{ }^{2}$ CaAlSiN ${ }_{3}: \mathrm{Ce}^{3+}, 6$ and $\mathrm{SrAl}_{-}$ $\mathrm{Si}_{4} \mathrm{~N}_{7}: \mathrm{Ce}^{3+}, 7$ have been developed and patented. Also, several oxide candidates such as $(\mathrm{Lu} / \mathrm{Y})_{3} \mathrm{MgAl}_{3} \mathrm{SiO}_{12}: \mathrm{Ce}^{3+}, \mathrm{Lu}_{3}(\mathrm{Al}, \mathrm{Mg})_{2^{-}}$ $(\mathrm{Al}, \mathrm{Si})_{3} \mathrm{O}_{12}: \mathrm{Ce}^{3+},{ }^{10} \mathrm{Y}_{3} \mathrm{Mg}_{2} \mathrm{AlSi}_{2} \mathrm{O}_{12}: \mathrm{Ce}^{3+}, 11,12$ or $\mathrm{LaSr}_{2} \mathrm{AlO}_{5}: \mathrm{Ce}^{3+},{ }^{13}$ are free from patent restriction and may be considered. Compared to the (oxy)nitride candidates, the oxide candidates have a lower synthesis cost and are easier to use in the form of ceramic plate (for application in emerging packaging techniques such as the remote phosphor arrangement ${ }^{14}$ which can reduce the thermal effect of the LED $p-n$ junction). 
Intending to develop a new yellow candidate with less rare earth element usage than YAG:Ce, in this paper, we report the $\mathrm{Y}_{2} \mathrm{BaAl}_{4} \mathrm{SiO}_{12}$ :Ce composition artificially created from YAG:Ce by using the solid state design, ${ }^{15-17}$ where a $\mathrm{YO}_{8}$ polyhedron is replaced by a $\mathrm{MO}_{8}[\mathrm{M}=$ barium $(\mathrm{Ba})$, calcium $(\mathrm{Ca})$, magnesium $(\mathrm{Mg})$ or strontium $(\mathrm{Sr})]$ and for charge neutrality, an $\mathrm{AlO}_{4}$ tetrahedron is simultaneously substituted by a $\mathrm{SiO}_{4}$ tetrahedron. This process is also called "chemical unit substitution". 18,19 The phase formation temperature for $\mathrm{Y}_{2} \mathrm{MAl}_{4} \mathrm{SiO}_{12}$ is also expected to decrease because of the $\mathrm{M}-\mathrm{Si}$ pair introduction. An essential concern regarding such a design is whether the new phosphor can retain the garnet structure and whether the luminescence will be readily comparable to YAG:Ce; this paper presents the results of these two questions. In addition, the $\mathrm{Y}_{2} \mathrm{MAl}_{4} \mathrm{SiO}_{12}$ :Ce powder sample contains highly crystalline micro semi-single crystals, which permits stable emission intensity against thermal quenching. This microstructure, which differs from the conventional ceramic-powder-phosphor or the single-crystal-phosphor, provides an inspiring insight for an important new type of phosphor, i.e., the microcrystal-glass powder phosphor.

\section{Experimental}

$(\mathrm{Y}, \mathrm{Ce})_{2} \mathrm{MAl}_{4} \mathrm{SiO}_{12}(\mathrm{M}=\mathrm{Ba}, \mathrm{Ca}, \mathrm{Mg}, \mathrm{Sr})$ phosphors were prepared by firing the mixtures of high purity oxides $(>99.9 \%)$, yttrium(III) oxide $\left(\mathrm{Y}_{2} \mathrm{O}_{3}\right)$, cerium(Iv) oxide $\left(\mathrm{CeO}_{2}\right)$, aluminium oxide $\left(\mathrm{Al}_{2} \mathrm{O}_{3}\right)$, silicon dioxide $\left(\mathrm{SiO}_{2}\right)$, and $\mathrm{MCO}_{3}(\mathrm{M}=\mathrm{Ba}, \mathrm{Ca}, \mathrm{Sr})$ or magnesium oxide $(\mathrm{MgO})$ in respective stoichiometric ratios. The powder mixtures were homogeneously ground and then placed in boron nitride crucibles, which were loaded into an alumina tubular furnace and heated at $1350-1450{ }^{\circ} \mathrm{C}$ with a holding time of 1-5 $\mathrm{h}$ in a reducing hydrogen (5\%)-nitrogen (95\%) atmosphere. Phosphor compositions referred to later in the paper are their nominal ones. The powder X-ray diffraction (XRD) data were collected on an X-ray diffractometer (SmartLab, Rigaku, Tokyo, Japan) with $\mathrm{CuK}_{\alpha}$ radiation (1.54056 ̊), operating at $45 \mathrm{kV}$ and $200 \mathrm{~mA}$ with a scan speed of $2^{\circ} \mathrm{min}^{-1}$. Crystal structure refinements employing the Rietveld method were implemented using TOPAS 4.2 software. ${ }^{20}$ Photoluminescence spectra were measured using a spectrofluorometer (FP-6500 Jasco, Tokyo, Japan) at room temperature. The emission stability against temperature increase $\left(30-200{ }^{\circ} \mathrm{C}\right)$ was investigated using a combined setup including a xenon lamp, a multichannel photodetector (MPCD-7000, Hamamatsu) and a computer controlled electric heater. The internal quantum efficiency (IQE) and external quantum efficiency (EQE) of the phosphor were determined on a phosphor quantum efficiency spectrophotometer (QE-1100, Otsuka Electronics, Japan), following the relationship of EQE $=\alpha \times \operatorname{IQE}(\alpha$ : absorption efficiency). The reflection spectrum of barium sulfate $\left(\mathrm{BaSO}_{4}\right)$ white standard was used for calibration. The crystallization behavior study was carried out on a scanning electron microscope (SEM; S-4300, Hitachi) equipped with a cathodoluminescence system (CL; MP32S/M, Horiba). The phosphor particles were embedded in epoxy resin and then cut using an argon ion cross section polisher (SM-09010, Jeol Ltd, Tokyo, Japan) for $18 \mathrm{~h}$. The beam current of the CL measurement was fixed at $100 \mathrm{pA}$ and the electron beam energy was set at $5 \mathrm{kV}$, which corresponds to a penetration depth of about $350 \mathrm{~nm}$.

\section{Results and discussion}

\subsection{Cation-size dependent phase formation behaviors}

Different phase formation behaviors depending on cation (M) size were observed in the $(\mathrm{Y}, \mathrm{Ce})_{2} \mathrm{MAl}_{4} \mathrm{SiO}_{12}$ series. As seen from Fig. 1, after heating at $1450{ }^{\circ} \mathrm{C}$ for $5 \mathrm{~h}$, the $\mathrm{M}=\mathrm{Ba} / \mathrm{Sr}$ analogues formed the crystalline garnet phase, whereas the $\mathrm{M}=\mathrm{Ca} / \mathrm{Mg}$ ones contained the garnet main phase and a secondary phase (such as $\mathrm{CaAl}_{2} \mathrm{SiO}_{7}$ or $\mathrm{MgAl}_{2} \mathrm{O}_{4}$ ). A broad diffraction band in the $25-35^{\circ}(2 \theta)$ range suggesting the existence of a secondary amorphous glass phase appears in the $\mathbf{M}=\mathrm{Ba}$ pattern and the intensity of this band decreases in that of $\mathrm{M}=\mathrm{Sr}$ and then disappears in those of the $\mathrm{Ca} / \mathrm{Mg}$ ones. As for the secondary crystalline phase, the corresponding amount in the $\mathbf{M}=\mathbf{M g}$ analogue is larger than that in the $\mathrm{Ca}$ analogue. Since some of the main phase atoms are in the glass phase, real chemical compositions of the $\mathrm{Ba} / \mathrm{Sr}$-members should differ slightly from the designed ones, which explains the fact that the evolution of cell volume $(V)$ against ionic radius (IR) of $\mathbf{M}$ does not show a wholly linear trend (Fig. S1, ESI $\dagger$ ). Such observations indicate an $\mathbf{M}$ cation size dependent phase formation behavior in the $(\mathrm{Y}, \mathrm{Ce})_{2} \mathrm{MAl}_{4} \mathrm{SiO}_{12}$ series: an $\mathrm{M}$ cation with a bigger size favors the single crystalline phase formation. If only considering the formation of crystalline phases, one may recognize it from the viewpoint of the garnet structure stability: when $\mathrm{YO}_{8} / \mathrm{AlO}_{4}$ are substituted by $\mathrm{MO}_{8} / \mathrm{SiO}_{4}$, a bigger $\mathrm{M}$ cation favors the stabilization of the artificial crystal lattice; whereas for smaller $\mathbf{M}$ cations, the lattice becomes less stable, which would be more likely to induce the formation of residue secondary phases.

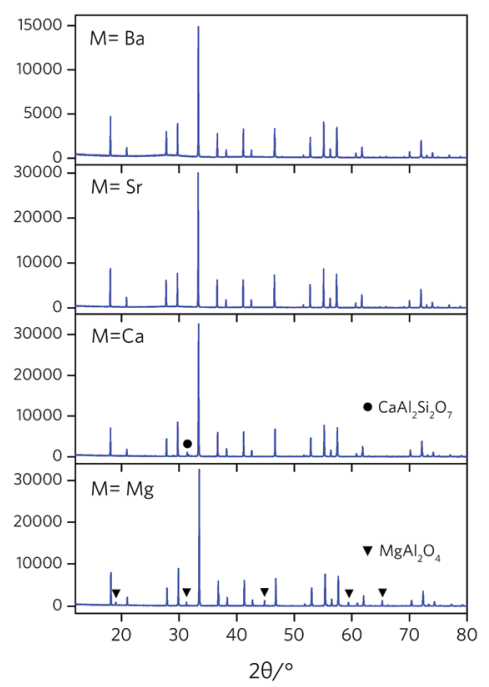

Fig. 1 XRD patterns of the samples with nominal composition of $\mathrm{Y}_{1.96} \mathrm{Ce}_{0.04} \mathrm{MAl}_{4} \mathrm{SiO}_{12}(\mathrm{M}=\mathrm{Ba}, \mathrm{Ca}, \mathrm{Mg}, \mathrm{Sr})$. 
$\mathrm{Al}^{3+}$ and $\mathrm{Si}^{4+}$ with a coordination number $(\mathrm{CN})$ of 4 have an effective IR of 0.39 and $0.26 \AA$, respectively. $\mathrm{Y}^{3+}, \mathrm{Ba}^{2+}, \mathrm{Sr}^{2+}, \mathrm{Ca}^{2+}$ and $\mathrm{Mg}^{2+}$ with a CN of 8 have IR of 1.019, 1.42, 1.26, 1.12 and $0.89 \AA$, respectively. ${ }^{21}$ Thus, substitution of Al by Si will contract the unit cell and a reasonable hypothesis is that the replacement of Y by a foreign cation with a bigger size will be more likely to stabilize the lattice. In contrast, the $\mathrm{Ca}$ or $\mathrm{Mg}$ that replaces $\mathrm{Y}$ is not favorably big, leading to a high tendency of impurity formation. A similar case with garnet where the cation size influences the structure stability has been reported for $\mathrm{Gd}_{3} \mathrm{Al}_{5} \mathrm{O}_{12}$ :Ce which is derived from $\mathrm{Lu}_{3} \mathrm{Al}_{5} \mathrm{O}_{12}$ :Ce by replacing lutetium (Lu; $0.977 \AA$ ) with gadolinium (Gd; $1.503 \AA$ ). The difference in IR between Gd and $\mathrm{Lu}$ is attributed as the intrinsic reason which makes GAG thermodynamically metastable above $1500{ }^{\circ} \mathrm{C}$ as well as the formation of the gadolinium aluminum perovskite $\left(\mathrm{GdAlO}_{3}\right)$ by-product. ${ }^{22,23}$ In 2013, the preparation of $\mathrm{Y}_{2} \mathrm{CaAl}_{4} \mathrm{SiO}_{12}$ using a sol-gel combustion route was reported (firstly annealing at $1000{ }^{\circ} \mathrm{C}$ for $2 \mathrm{~h}$ and subsequently sintering at $1450{ }^{\circ} \mathrm{C}$ for $\left.4 \mathrm{~h}\right) .^{24}$ The sample contained a small amount of $\mathrm{Ca}_{2} \mathrm{Al}_{2} \mathrm{SiO}_{7}$ impurity. In the case of $\mathrm{Lu}_{2} \mathrm{CaAl}_{4} \mathrm{SiO}_{12}$, however, it was found that $\mathrm{Lu}_{2} \mathrm{CaAl}_{4} \mathrm{SiO}_{12}$ prepared at $1400{ }^{\circ} \mathrm{C}$ for $4 \mathrm{~h}$ formed a pure garnet phase. ${ }^{25}$ This suggests that the crystal lattice of $\mathrm{Lu}_{2} \mathrm{CaAl}_{4} \mathrm{SiO}_{12}$ is more likely to be stable than that of $\mathrm{Y}_{2} \mathrm{CaAl}_{4} \mathrm{SiO}_{12}$, which confirms that the phase formation behavior depends on the cation size. A recent study ${ }^{26}$ demonstrated the synthesis of $\mathrm{Y}_{2} \mathrm{MgAl}_{4} \mathrm{SiO}_{12}$ :Ce at $1300-1400{ }^{\circ} \mathrm{C}$ with a prolonged holding period of $12 \mathrm{~h}$ together with an intermediate preheating (at $1000{ }^{\circ} \mathrm{C}$ for $8 \mathrm{~h}$ ) gave an almost pure phase. Thus, the claim of " $M$ cation size dependent phase formation behavior in the $(\mathrm{Y}, \mathrm{Ce})_{2} \mathrm{MAl}_{4} \mathrm{SiO}_{12}$ series" stresses that a bigger $\mathrm{M}$ cation favors a pure garnet phase formation, but it does not necessarily mean that the $\mathbf{M}=\mathrm{Ca} / \mathrm{Mg}$ analogues are not able to form a pure phase.

In addition, the amorphous phase formation in the $\mathrm{M}=\mathrm{Ba}$ pattern may be related to the level of $\mathrm{Ba}-\mathrm{Si}$ substituting for $\mathrm{Y}-\mathrm{Al}$ in YAG. To verify this effect, a set of $\mathrm{Y}_{2.96-x} \mathrm{Ba}_{x} \mathrm{Ce}_{0.04} \mathrm{Al}_{5-x} \mathrm{Si}_{x} \mathrm{O}_{12}$ $(x=0.8,0.6)$ samples were prepared by heating at $1400{ }^{\circ} \mathrm{C}$ for $2 \mathrm{~h}$. The broad diffraction band in the XRD patterns can still be observed in these samples; however, when comparing their normalized ones (Fig. S2, ESI $\dagger$ ), it is clear that with decreasing Ba-Si substitution level from $x=1.0$ to $x=0.6$, the intensity of this broad band gradually decreases, suggesting a decreased glass-phase/crystalline-phase ratio in these products. Thus, in addition to the $\mathrm{M}$ cation type, the amount of glass phase in the $\mathrm{Y}_{2} \mathrm{MAl}_{4} \mathrm{SiO}_{12}$ phosphors also depends on the $\mathrm{M}-\mathrm{Si} / \mathrm{Y}-\mathrm{Al}$ substitution level.

\subsection{Photoluminescence of $\mathrm{Y}_{2} \mathrm{MAl}_{4} \mathrm{SiO}_{12}$ : $\mathrm{Ce}$}

The emission spectra of the powder samples under $\lambda_{\mathrm{ex}}=460 \mathrm{~nm}$ are shown in Fig. 2. The broad asymmetric emission of $\mathrm{Y}_{1.96} \mathrm{Ce}_{0.04} \mathrm{BaAl}_{4} \mathrm{SiO}_{12}$ with a doublet structure feature originates from the energy transition of the lowest $\mathrm{Ce}^{3+} 5 \mathrm{~d}$ excited state to the two $4 \mathrm{f}$ ground states $\left({ }^{2} \mathrm{~F}_{5 / 2}\right.$ and $\left.{ }^{2} \mathrm{~F}_{7 / 2}\right)$. From $\mathrm{M}=\mathrm{Ba}$ to $\mathrm{Mg}$, the emission maximums gradually red-shift from 534 to $552 \mathrm{~nm}$ (Table 1), suggesting an increasing crystal field splitting of the Ce $5 \mathrm{~d}$ levels. This is because of the fact that with the decreasing $\mathbf{M}$ cation size in the lattice, the unit cell volume

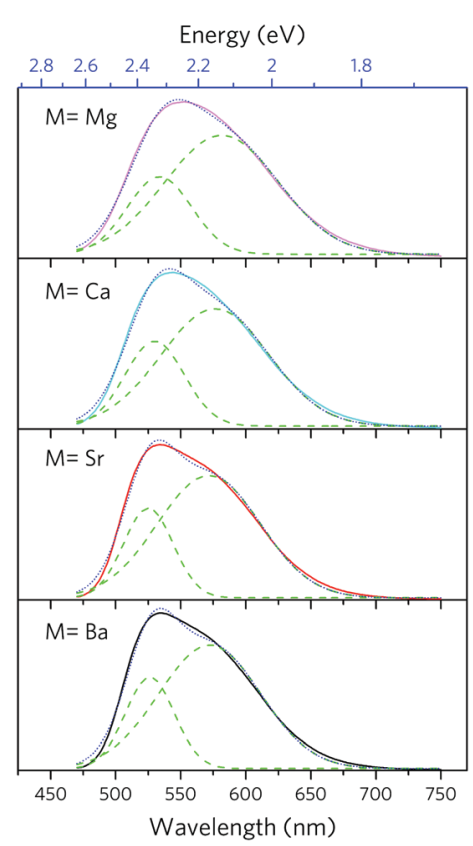

Fig. 2 Emission spectra $\left(\lambda_{\mathrm{ex}}=460 \mathrm{~nm}\right)$ of the phosphor series with nominal compositions of $\mathrm{Y}_{1.96} \mathrm{Ce}_{0.04} \mathrm{MAl}_{4} \mathrm{SiO}_{12}(\mathrm{M}=\mathrm{Ba}, \mathrm{Ca}, \mathrm{Mg}, \mathrm{Sr}$ ). The green curves show the Gaussian-type fitting.

decreases and the bond lengths of Ce with coordinating $\mathrm{O}$ atoms become shortened. The evolution from the $\mathrm{M}=\mathrm{Ba}$ to $\mathrm{M}=\mathrm{Sr}$ bands does not show the obvious red-shift effect, probably because of amorphous phase formation in the $\mathbf{M}=\mathrm{Ba}$ samples which leads the intrinsic formula away from the designed $\mathrm{Y}_{2} \mathrm{BaAl}_{4} \mathrm{SiO}_{12}$ :Ce. The full-width at half-maximum (fwhm) values of the spectra show an increasing trend from $0.4242 \mathrm{eV}$ to $0.4522 \mathrm{eV}$ by $6.7 \%$ (Table 1 ) and such a broadening of the spectra suggest a more diverse coordination environments for Ce ions. The spectra were further analyzed using Gaussian fitting (Fig. 2) and the component fit-band 2 shows a more extreme red-shift and broadening than the fit-band 1 (Table 1). Generally, there is no difference in red-shift between these two bands because the energy difference between the two uf states should remain the same. This feature observed here together with the broadening may be caused by some inhomogeneity in the emission as a consequence of Ce ions in slightly different local environments having different emission energy. In addition, the relative intensities of the two Gaussian components vary among these spectra and therefore, the well resolved fine structure feature becomes gradually less distinguishable and the spectra become somewhat symmetric for the $\mathrm{M}=\mathrm{Ca} / \mathrm{Mg}$ analogues. The $\mathrm{M}=\mathrm{Ba}$ and $\mathrm{Ca}$ samples give $\mathrm{a}$ relatively high emission intensity, whereas the emissions of the $\mathrm{Sr} / \mathrm{Mg}$ analogue are low (probably because of the co-existence of impurity phases).

The peaking emission of $\mathrm{Y}_{2} \mathrm{CaAl}_{4} \mathrm{SiO}_{12}$ :Ce has been reported by Katelnikovas et al., ${ }^{24}$ which shows a shift from 542 to $560 \mathrm{~nm}$ upon variation of the Ce concentrations. The emission maximum of the $\mathrm{M}=\mathrm{Ca}$ phosphor in this study locates at $544 \mathrm{~nm}$, which is consistent with previous results. In addition, the emission maximum of $\mathrm{Lu}_{2} \mathrm{CaAl}_{4} \mathrm{SiO}_{12}$ :Ce is reported to be in the range of 
Table 1 Peaking wavelength and full-width at half-maximum (fwhm) of the $\mathrm{Y}_{1.96} \mathrm{Ce}_{0.04} \mathrm{MAl}_{4} \mathrm{SiO}_{12}$ series emissions

\begin{tabular}{|c|c|c|c|c|}
\hline Samples & $\mathrm{M}=\mathrm{Ba}$ & $\mathrm{M}=\mathrm{Sr}$ & $\mathrm{M}=\mathrm{Ca}$ & $M=M g$ \\
\hline Fit-band 1: peak; fwhm (nm) & $526 ; 44$ & $526 ; 44$ & $529 ; 53$ & $522 ; 58$ \\
\hline Fit-band 2: peak; fwhm (nm) & $572 ; 92$ & $572 ; 92$ & $576 ; 98$ & $581 ; 103$ \\
\hline
\end{tabular}

520-542 nm, ${ }^{25}$ which shows a blue-shift compared to $\mathrm{Y}_{2} \mathrm{CaAl}_{4} \mathrm{SiO}_{12}: \mathrm{Ce}$ because of a lower crystal field splitting.

\subsection{Crystal structure of $\mathrm{Y}_{2} \mathrm{BaAl}_{4} \mathrm{SiO}_{12}$}

Fig. 3 shows the XRD refinement plot of $\mathrm{Y}_{1.96} \mathrm{Ce}_{0.04} \mathrm{BaAl}_{4} \mathrm{SiO}_{12}$ sample and the scale of the $y$-axis in the difference Rietveld plot was square-rooted twice to clearly reveal the broad diffraction band and the high angle diffractions. All crystalline peaks are able to be indexed by cubic cell $(\operatorname{Ia} \overline{3} d)$ with parameters close to $\mathrm{Y}_{3} \mathrm{Al}_{5} \mathrm{O}_{12}$ whose crystal structure was then taken as a starting model for the refinement of this pattern. In the process, the site of the $\mathrm{Al} 1$ ion (in the tetrahedral site) was occupied by $\mathrm{Al} / \mathrm{Si}$ ions with a fixed occupancy of $2 / 3$ and $1 / 3$, respectively. The $Y$ site was occupied by the $\mathrm{Ba} / \mathrm{Y} / \mathrm{Ce}$ ions with fixed occupancy according to the suggested formula. The process was stable and ended with low $R$-factors (Table 2 and Fig. 3), indicating the validity of the refinement. Coordinates of each atom and the main bond lengths are listed in Tables 3 and 4, respectively. The crystallographic information file (CIF) is provided in the ESI. $\dagger$ The unit cell of $\mathrm{Y}_{2} \mathrm{BaAl}_{4} \mathrm{SiO}_{12}$ is depicted in Fig. 4, where the coordination situation of polyhedrons $(\mathrm{Y} / \mathrm{Ba}) \mathrm{O}_{8}, \mathrm{AlO}_{6}$ and $(\mathrm{Al}, \mathrm{Si}) \mathrm{O}_{4}$ is shown. The $\mathrm{Y}_{2} \mathrm{BaAl}_{4} \mathrm{SiO}_{12}$ is able to preserve the garnet structure and the introduced $\mathrm{Ba}$ and $\mathrm{Si}$ atoms occupy the $\mathrm{Y}$ and $\mathrm{Al}$ (in the $\mathrm{AlO}_{4}$ tetrahedron) sites, respectively.

\subsection{Emission optimization of $\mathrm{Y}_{2} \mathrm{BaAl}_{4} \mathrm{SiO}_{12}: \mathrm{Ce}$}

The synthesis conditions were further varied on aspects of temperature and holding period. First, a set of samples were prepared at $1400{ }^{\circ} \mathrm{C}$ and held for 1,2 or $4 \mathrm{~h}$. In this group, the

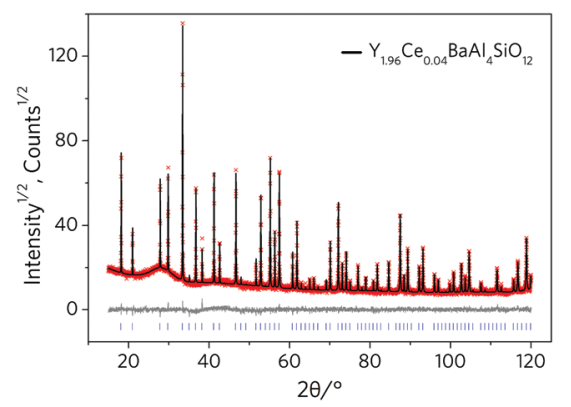

Fig. 3 Observed (black), calculated (red), and difference (gray) XRD profiles for the refinement of the $\mathrm{Y}_{1.96} \mathrm{Ce}_{0.04} \mathrm{BaAl}_{4} \mathrm{SiO}_{12}$ sample using the Rietveld method. Bragg reflections are indicated with vertical marks.
Table 3 Fractional atomic coordinates and isotropic displacement parameters $\left(\AA^{2}\right)$ of $\mathrm{Y}_{1.96} \mathrm{Ce}_{0.04} \mathrm{BaAl}_{4} \mathrm{SiO}_{12}$

\begin{tabular}{llllll}
\hline & $x$ & $y$ & $z$ & $B_{\text {iso }}$ & Occ. \\
\hline $\mathrm{Ba}$ & 0 & $1 / 4$ & $1 / 8$ & $1.01(5)$ & $1 / 3$ \\
$\mathrm{Y}$ & 0 & $1 / 4$ & $1 / 8$ & $1.01(5)$ & $49 / 75$ \\
$\mathrm{Ce}$ & 0 & $1 / 4$ & $1 / 8$ & $1.01(5)$ & $1 / 75$ \\
$\mathrm{Al} 1$ & 0 & $1 / 4$ & $3 / 8$ & $0.30(6)$ & $2 / 3$ \\
$\mathrm{Si} 1$ & 0 & $1 / 4$ & $3 / 8$ & $0.30(6)$ & $1 / 3$ \\
$\mathrm{Al} 2$ & 0 & 0 & 0 & $0.30(8)$ & 1 \\
$\mathrm{O}$ & $-0.0299(3)$ & $0.0490(3)$ & $0.1490(3)$ & $0.7(1)$ & 1
\end{tabular}

Table 4 Main bond lengths ( $(\AA)$ of $\mathrm{Y}_{1.96} \mathrm{Ce}_{0.04} \mathrm{BaAl}_{4} \mathrm{SiO}_{12}$

\begin{tabular}{llll}
\hline$(\mathrm{Ba} / \mathrm{Y} / \mathrm{Ce})-\mathrm{O}$ & $2.457(4)$ & $(\mathrm{Al} 1 / \mathrm{Si} 1)-\mathrm{O}^{\mathrm{ii}}$ & $1.767(4)$ \\
$(\mathrm{Ba} / \mathrm{Y} / \mathrm{Ce})-\mathrm{O}^{\mathrm{i}}$ & $2.297(2)$ & $\mathrm{Al} 2-\mathrm{O}$ & $1.924(4)$
\end{tabular}

Symmetry codes: (i) $-y,-z+1 / 2, x$; (ii) $-y, z, x+1 / 2$.

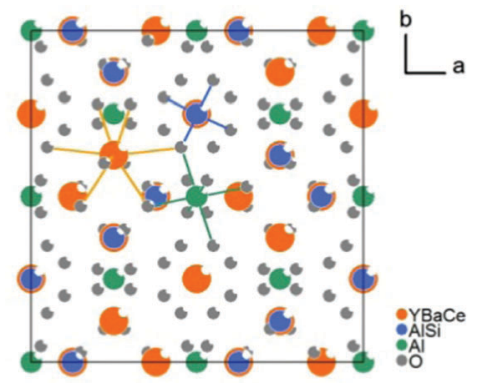

Fig. 4 Unit cell structure of $\mathrm{Y}_{2} \mathrm{BaAl}_{4} \mathrm{SiO}_{12}$ viewed along the $c$ axis, showing a typical cubic garnet structure. Ba ions occupy the $\mathrm{Y}$ site, and $\mathrm{Si}$ ions occupy the $\mathrm{Al}$ site in the $\mathrm{AlO}_{4}$ tetrahedron.

one sintered for $2 \mathrm{~h}$ gives a higher emission intensity. Then, with a holding time of $2 \mathrm{~h}$, two other samples were heated at $1300{ }^{\circ} \mathrm{C}$ or $1350{ }^{\circ} \mathrm{C}$. However, these samples contained the garnet main phase and different amounts of barium aluminate $\left(\mathrm{BaAl}_{2} \mathrm{O}_{4}\right)$ secondary phase (Fig. S3, ESI $\dagger$ ). Thus, the sintering parameters of $1400{ }^{\circ} \mathrm{C}$ for $2 \mathrm{~h}$ were chosen. Under this condition, a series of $\mathrm{Y}_{2-y} \mathrm{Ce}_{y} \mathrm{BaAl}_{4} \mathrm{SiO}_{12}(y=0.02,0.04,0.06,0.08)$ were prepared to optimize the Ce doping concentration; among these samples, the $y=0.08$ sample gave the highest emission intensity. The concentration quenching effect does not occur with such a high Ce doping level, probably because of the fact that some Ce may exist in the amorphous phase. The emission peak slightly

Table 2 Main parameters of processing and refinement of $\mathrm{Y}_{1.96} \mathrm{Ce}_{0.04} \mathrm{BaAl}_{4} \mathrm{SiO}_{12}$

\begin{tabular}{llllll}
\hline Phase & Weight (\%) & Space group & Cell parameter $(\AA)$, volume $\left(\AA^{3}\right)$ & $R_{\mathrm{B}}(\%)$ & $R_{\mathrm{p}}, R_{\mathrm{wp}}(\%), \chi^{2}$ \\
\hline $\mathrm{Y}_{1.96} \mathrm{Ce}_{0.04} \mathrm{BaAl}_{4} \mathrm{SiO}_{12}$ & 100 & Ia $\overline{3} d$ & $\begin{array}{l}a=12.00680(5) \\
V=1730.94(2)\end{array}$ & 3.38 & $6.84,9.12,1.29$
\end{tabular}




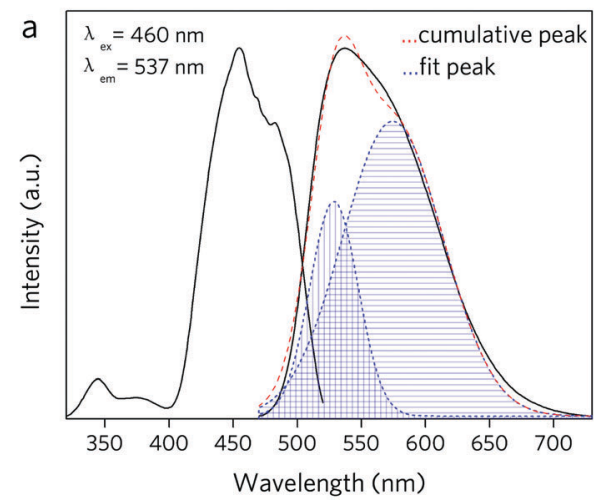

$b$

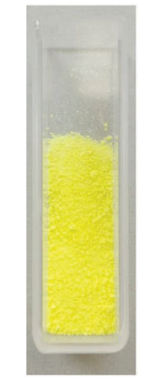

Fig. 5 (a) Emission and excitation spectra of $\mathrm{Y}_{1.92} \mathrm{Ce}_{0.08} \mathrm{BaAl}_{4} \mathrm{SiO}_{12}$ and the blue curves give the Gaussian fitting components. (b) Digital image of the phosphor under sunlight.

red-shifts to a longer wavelength as the Ce content increases.

The $y=0.08$ phosphor shows a broad emission band (Fig. 5a) with an intense yellow body-color (Fig. 5b). The excitation spectrum shows the maximum intensity at $455 \mathrm{~nm}$, which matches well with the emission of the current efficient blue LEDs $(420-460 \mathrm{~nm}) .^{3}$ The fwhm of the emission band is $104 \mathrm{~nm}$, which is similar to that of $\mathrm{Y}_{3} \mathrm{Al}_{5} \mathrm{O}_{12}$ : $\mathrm{Ce}(\sim 104 \mathrm{~nm})$, but smaller than that of other garnet phosphors such as $(\mathrm{Lu}, \mathrm{Y})_{3} \mathrm{MgAl}_{3} \mathrm{SiO}_{12}$ :Ce $(137-147 \mathrm{~nm}){ }^{8}{ }^{8}$ The higher energy band $(320-400 \mathrm{~nm})$ of the excitation is much weaker than that of its low energy counterpart (400-520 nm). In comparison, the excitation of a typical YAG:Ce powder shows high and low energy bands of nearly equal intensity. ${ }^{24} \mathrm{~A}$ similar feature has been reported for $\mathrm{Y}_{2} \mathrm{CaAl}_{4} \mathrm{SiO}_{12}$ :Ce, ${ }^{24}$ which experienced more severe photoionization at lower excitation energies in comparison to YAG:Ce; such a mechanism is also expected to explain the features observed for $\mathrm{Y}_{2} \mathrm{BaAl}_{4} \mathrm{SiO}_{12}$ :Ce.

Under $\lambda_{\mathrm{ex}}=460 \mathrm{~nm}$, the $y=0.08$ sample exhibits an absorption efficiency of $80.2 \%$, IQE of $95.2 \%$ and EQE of $76.4 \%$, which shows a relatively high efficiency performance for the $\mathrm{Y}_{2} \mathrm{BaAl}_{4} \mathrm{SiO}_{12}: \mathrm{Ce}^{3+}$ phosphor. The existence of a glass phase may affect the absorption of incident photons by phosphor particles; thus, either a post-treatment (such as removal of the glass with etching) or designing the substitution of $\mathrm{Ba} / \mathrm{Si}$ for $\mathrm{Y} / \mathrm{Al}$ at a lower level may probably help improve the absorption efficiency.

\subsection{Temperature dependent emission of $\mathrm{Y}_{2} \mathrm{BaAl}_{4} \mathrm{SiO}_{12}$ :Ce}

Although new packaging configurations such as the phosphorin-glass, the remote-phosphor-arrangement and the singlecrystal-phosphor were proposed as promising routes to reduce the thermal effect of the LED p-n junction on the phosphor emission, direct coating of the phosphor-polymer mixture onto the LED chip is still the mainstream in the current market. Thus, it is of practical interest to evaluate the thermal emission stability of a new phosphor.

Emission spectra $\left(\lambda_{\mathrm{ex}}=460 \mathrm{~nm}\right)$ of $\mathrm{Y}_{1.92} \mathrm{Ce}_{0.08} \mathrm{BaAl}_{4} \mathrm{SiO}_{12}$ over the temperature range $30-200{ }^{\circ} \mathrm{C}$ are shown in Fig. 6 . The emission intensity decreased with increasing temperature because
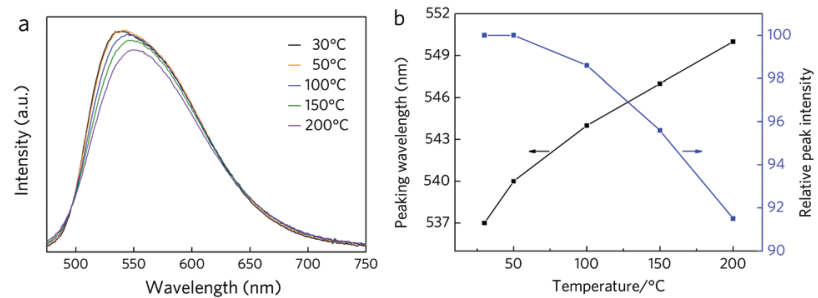

Fig. 6 (a) Emission spectra $\left(\lambda_{\mathrm{ex}}=460 \mathrm{~nm}\right)$ of $\mathrm{Y}_{1.92} \mathrm{Ce}_{0.08} \mathrm{BaAl}_{4} \mathrm{SiO}_{12}$ as recorded over the temperature range $30-200{ }^{\circ} \mathrm{C}$. (b) Evolution of the peaking wavelength and the relative peak intensity against temperature increase.

of thermal quenching. The intensity of the emission peak, when tested at $200{ }^{\circ} \mathrm{C}$, becomes $91.5 \%$ of that measured at $30{ }^{\circ} \mathrm{C}$, demonstrating a high stability against the thermal effect, which is quite close to that reported for a single-crystal YAG:Ce phosphor. ${ }^{27}$ As the temperature increases, the emission maximum shifts towards longer wavelengths and a similar red-shift effect was also observed for a YAG:Ce single-crystal phosphor, ${ }^{28}$ which was explained by the temperature dependent absorption and the temperature dependent emission decay of the two Gaussian components. Overall, the emission stability against thermal effect of the $\mathrm{Y}_{2} \mathrm{BaAl}_{4} \mathrm{SiO}_{12}: \mathrm{Ce}^{3+}$ phosphor is relatively high which may enable it to be used in high-powder WLEDs.

\subsection{Crystallization behavior of $\mathrm{Y}_{2} \mathrm{BaAl}_{4} \mathrm{SiO}_{12}$ : $\mathrm{Ce}$}

The combined technique of scanning electron microscope and cathodoluminescence (SEM-CL) was employed to characterize the binding situation and respective morphology/emission of the amorphous and crystalline phases. The characterization was performed on the cross-sectional area of $\mathrm{Y}_{1.92} \mathrm{Ce}_{0.08} \mathrm{BaAl}_{4} \mathrm{SiO}_{12}$. The SEM image shows isolated crystals embedding in the particle matrix (Fig. 7a). The CL emission spectrum measured for the phosphor particle consists of a dominating band peaking at $540 \mathrm{~nm}$ and a weak shoulder peaking at $360 \mathrm{~nm}$. Monochromatic CL mapping images taken for these two emissions suggest that both of the two emission bands originate from the crystalline crystals because the bright sections are almost identical (Fig. $7 \mathrm{~b}$ and c). The emitting sections at $540 \mathrm{~nm}$ in Fig. $7 \mathrm{~b}$ indicate a relatively uniform distribution, and the local bright crystals (diameter of $\sim 1 \mu \mathrm{m}$ ) tend to be of spherical shape, which may be induced by the intrinsic cubic structure governed crystallization. The point-dependent CL studies show that the dark points (points 5 and 10) of the particles give no emission and different bright points give the $540 \mathrm{~nm}$ and $360 \mathrm{~nm}$ emissions with different relative intensities. Previously, this ultraviolet band $(360 \mathrm{~nm})$ emission has been observed for undoped YAG powder and attributed to an excitonic emission localized near the anti-site defect $\mathrm{Y}^{3+}{ }_{\mathrm{Al}}{ }^{29,30}$

The CL mapping demonstrates that the bright luminescent crystals are uniformly embedded in the dark non-emitting amorphous phase within the cross-sectional area. Such a binding situation may suggest crystallization behavior of $\mathrm{Y}_{2} \mathrm{BaAl}_{4} \mathrm{SiO}_{12}$ crystals from the melt during high temperature sintering or, the nucleation starts at low temperature with a conventional solid 

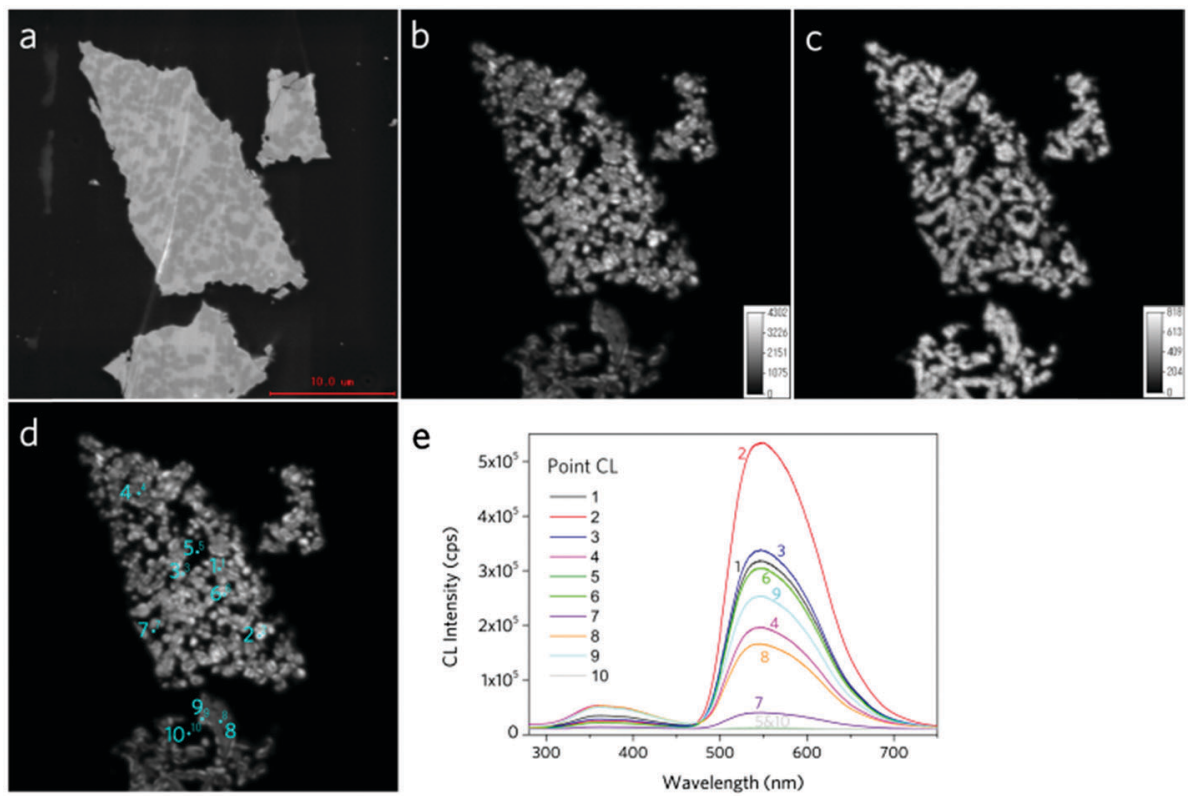

Fig. 7 Cross-sectional SEM images of the phosphor particles (a) (scale bar: $10 \mu \mathrm{m}$ ); CL mapping taken for the $540 \mathrm{~nm}$ emission (b) and $360 \mathrm{~nm}$ emission (c). Point CL study was performed on the particles (d) and the corresponding emission spectra are given in (e).

state reaction with the following crystal growth significantly favoured by the melt generation at a higher temperature. More elaborate studies are awaited to verify these claims. The micro $\mathrm{Y}_{2} \mathrm{BaAl}_{4} \mathrm{SiO}_{12}$ crystals are highly crystalline and they prefer to be close to the single-crystal rather than to the conventional ceramic powder. This mechanism explains the high thermal emission stability (Fig. 6).

Although the preparation uses the conventional solid state reaction route, the $\mathrm{Y}_{2} \mathrm{BaAl}_{4} \mathrm{SiO}_{12}$ :Ce powder obtained contains micro semi-single-crystals. This feature shares some similarity with the glass-ceramic phosphor ${ }^{31,32}$ which also contains both crystals and glass, but is different from either the single-crystalphosphor or the ceramic-powder-phosphor. The differences are compared in Fig. 8. The melt assisted precipitation-growth mechanism is also different from the diffusion-nucleationgrowth in the solid state reaction. The melt formation is different from the situation that occurred in the glass-ceramic phosphor, which is in situ generated because of the formation of some low temperature eutectic components with barium oxide-silicon dioxide $\left(\mathrm{BaO}-\mathrm{SiO}_{2}\right)$ addition. This kind of structure

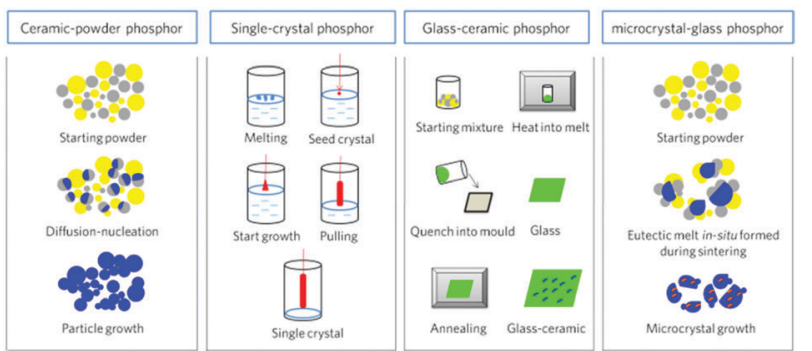

Fig. 8 Comparison of the preparation/crystallization between the ceramicpowder phosphor, the single-crystal phosphor, the glass-ceramic phosphor and the microcrystal-glass powder phosphor. may be referred to as a "microcrystal-glass powder phosphor" to demonstrate the combination of "powder" and "microcrystal" features. The exact substitution contents of Ce into the $\mathrm{Y}_{2} \mathrm{BaAl}_{4}$ $\mathrm{SiO}_{12}$ microcrystals may be lower than the designed nominal ratios, but Ce incorporation should not be that difficult as in the case of the single-crystal-phosphor (in which problems of Ce-doping solubility and gradient segregation need to be addressed ${ }^{28}$ ). In comparison, the microcrystal-glass powder phosphor can avoid these disadvantages but shares the merit of high emission stability. A recent tentative study suggests that $\mathrm{Y}_{2} \mathrm{BaAl}_{4} \mathrm{SiO}_{12}$ is highly likely to form a dense ceramic phosphor under vacuum sintering, which opens more application opportunities for this phosphor.

\section{Conclusions}

A new $(\mathrm{Y}, \mathrm{Ce})_{2} \mathrm{BaAl}_{4} \mathrm{SiO}_{12}$ phosphor was developed using a solid solution method starting from $\mathrm{Y}_{3} \mathrm{Al}_{5} \mathrm{O}_{12}$ : :e using polyhedron substitution $\left(\mathrm{BaO}_{8} / \mathrm{SiO}_{4}\right.$ for $\left.\mathrm{YO}_{8} / \mathrm{AlO}_{4}\right)$. The $\mathrm{Y}_{2} \mathrm{MAl}_{4} \mathrm{SiO}_{12}$ series $(\mathrm{M}=\mathrm{Ba}, \mathrm{Ca}, \mathrm{Mg}, \mathrm{Sr}$ ) shows a cation (M) size dependent phase formation behavior and a bigger $\mathrm{M}$ cation in the formula favors the formation of a single crystalline garnet phase. For the Ba-analogue, the amount of amorphous phase in the product also depends on the Ba-Si for Y-Al substitution level. The newly developed $\mathrm{Y}_{2} \mathrm{BaAl}_{4} \mathrm{SiO}_{12}$ successfully saves the original garnet structure of YAG. When doped with Ce ions, it absorbs blue light and can efficiently emit yellow light in the spectral range of 470-700 $\mathrm{nm}$. The broad asymmetric emission can be decomposed into two Gaussian emission components originating from the energy transition from the lowest $\mathrm{Ce} 5 \mathrm{~d}$ state to two $4 \mathrm{f}$ states. The highly crystalline nature of the submicron $\mathrm{Y}_{2} \mathrm{BaAl}_{4} \mathrm{SiO}_{12}$ crystals explains the high emission stability against the thermal effect and 
the formation of such morphology relates to the melt generation during high temperature sintering. The development of $\mathrm{Y}_{2} \mathrm{BaAl}_{4} \mathrm{SiO}_{12}$ :Ce guarantees the formation of a $\mathrm{Y}_{3-x} \mathrm{Ba}_{x} \mathrm{Al}_{5-x} \mathrm{Si}_{x} \mathrm{O}_{12}$ : Ce $(0<x<1)$ series which provides the possibility to reduce the use of rare earth elements in commercial YAG and potentially eliminate intellectual property conflict. This study also provides an inspiring insight to preparing the microcrystal-glass powder phosphor, which is distinguished from conventional ceramicpowder-phosphor (because of improved emission stability against thermal quenching) or single-crystal-phosphor (because of the lower preparation cost).

\section{Acknowledgements}

This study was partially supported by the National Natural Science Foundation of China (Grant No. 51272259, 51572232 and 51561135015). R. X. was also partially supported by the JSPS KAKENHI (No. 15K06448). M. M. and Z. X. were also partially supported by the Russian Foundation for Basic Research (No. 15-52-53080). H. J. thanks the China Scholarship Council (CSC) for scholarship support.

\section{References}

1 P. Pust, P. J. Schmidt and W. Schnick, Nat. Mater., 2015, 14, 454-458.

2 R.-J. Xie, N. Hirosaki, K. Sakuma, Y. Yamamoto and M. Mitomo, Appl. Phys. Lett., 2004, 84, 5404-5406.

3 A. Piquette, W. Bergbauer, B. Galler and K. C. Mishra, ECS J. Solid State Sci. Technol., 2016, 5, R3146-R3159.

4 V. Bachmann, C. Ronda, O. Oeckler, W. Schnick and A. Meijerink, Chem. Mater., 2009, 21, 316-325.

5 T. Suehiro, N. Hirosaki and R.-J. Xie, ACS Appl. Mater. Interfaces, 2011, 3, 811-816.

6 Y. Q. Li, N. Hirosaki, R. J. Xie, T. Takeda and M. Mitomo, Chem. Mater., 2008, 20, 6704-6714.

7 J. Ruan, R.-J. Xie, S. Funahashi, Y. Tanaka, T. Takeda, T. Suehiro, N. Hirosaki and Y.-Q. Li, J. Solid State Chem., 2013, 208, 50-57.

8 H. Ji, L. Wang, M. Molokeev, N. Hirosaki, Z. Huang, Z. Xia, O. M. ten Kate, L. Liu and R.-J. Xie, J. Mater. Chem. C, 2016, 4, 2359-2366.

9 Y. Shi, G. Zhu, M. Mikami, Y. Shimomura and Y. Wang, Dalton Trans., 2015, 44, 1775-1781.

10 H. Ji, L. Wang, M. S. Molokeev, N. Hirosaki, R. Xie, Z. Huang, Z. Xia, O. M. ten Kate, L. Liu and V. V. Atuchin, J. Mater. Chem. C, 2016, 4, 6855-6863.

11 A. Katelnikovas, H. Bettentrup, D. Uhlich, S. Sakirzanovas, T. Jüstel and A. Kareiva, J. Lumin., 2009, 129, 1356-1361.
12 A. Katelnikovas, T. Bareika, P. Vitta, T. Jüstel, H. Winkler, A. Kareiva, A. Žukauskas and G. Tamulaitis, Opt. Mater., 2010, 32, 1261-1265.

13 W. B. Im, N. N. Fellows, S. P. DenBaars, R. Seshadri and Y.-I. Kim, Chem. Mater., 2009, 21, 2957-2966.

14 S.-P. Ying and A.-Y. Shiu, Appl. Opt., 2015, 54, E30-E34.

15 H. Ji, Z. Huang, Z. Xia, M. S. Molokeev, V. V. Atuchin, M. Fang and Y. Liu, J. Phys. Chem. C, 2015, 119, 2038-2045.

16 H. Ji, Z. Huang, Z. Xia, M. S. Molokeev, V. V. Atuchin and S. Huang, Inorg. Chem., 2014, 53, 11119-11124.

17 H. Ji, Z. Huang, Z. Xia, M. S. Molokeev, V. V. Atuchin, M. Fang and S. Huang, Inorg. Chem., 2014, 53, 5129-5135.

18 Z. Xia, C. Ma, M. S. Molokeev, Q. Liu, K. Rickert and K. R. Poeppelmeier, J. Am. Chem. Soc., 2015, 137, 12494-12497.

19 Z. Xia, G. Liu, J. Wen, Z. Mei, M. Balasubramanian, M. S. Molokeev, L. Peng, L. Gu, D. J. Miller, Q. Liu and K. R. Poeppelmeier, J. Am. Chem. Soc., 2016, 138, 1158-1161.

20 TOPAS V4.2: General profile and structure analysis software for powder diffraction data - User's Manual, Bruker AXS: Karlsruhe, Germany, 2008.

21 R. Shannon, Acta Crystallogr., Sect. A: Found. Crystallogr., 1976, 32, 751-767.

22 C.-C. Chiang, M.-S. Tsai and M.-H. Hon, J. Electrochem. Soc., 2007, 154, J326-J329.

23 J. Li, J.-G. Li, Z. Zhang, X. Wu, S. Liu, X. Li, X. Sun and Y. Sakka, J. Am. Ceram. Soc., 2012, 95, 931-936.

24 A. Katelnikovas, S. Sakirzanovas, D. Dutczak, J. Plewa, D. Enseling, H. Winkler, A. Kareiva and T. Jüstel, J. Lumin., 2013, 136, 17-25.

25 A. Katelnikovas, J. Plewa, D. Dutczak, S. Möller, D. Enseling, H. Winkler, A. Kareiva and T. Jüstel, Opt. Mater., 2012, 34, 1195-1201.

26 Z. Pan, W. Li, Y. Xu, Q. Hu and Y. Zheng, RSC Adv., 2016, 6, 20458-20466.

27 A. Stelian, G. V. Encarnación, I. Daisuke, A. Kazuo, S. Yoshiyuki and S. Kiyoshi, Mater. Res. Express, 2014, 1, 025041.

28 A. Stelian, G. V. Encarnación, I. Daisuke, A. Kazuo, S. Yoshiyuki and S. Kiyoshi, Mater. Res. Express, 2015, 2, 055503.

29 V. Babin, K. Blazek, A. Krasnikov, K. Nejezchleb, M. Nikl, T. Savikhina and S. Zazubovich, Phys. Status Solidi C, 2005, 2, 97-100.

30 S. Arjoca, G. Villora, D. Inomata, Y. Arai, Y. Cho, T. Sekiguchi and K. Shimamura, J. Ceram. Soc. Jpn., 2016, 124, 574-578.

31 S. Fujita and S. Tanabe, Int. J. Appl. Glass Sci., 2015, 6, 356-363.

32 D. Chen, W. Xiang, X. Liang, J. Zhong, H. Yu, M. Ding, H. Lu and Z. Ji, J. Eur. Ceram. Soc., 2015, 35, 859-869. 